\title{
Pendidikan Karakter (Akhlak) Dalam Perspektif Islam
}

\section{Zulfatus Sobihah}

\author{
Institut Agama Islam Negeri (IAIN) Purwokerto
}

Jl. A. Yani No.40A, Karanganjing, Purwanegara, Kec. Purwokerto Utara, Kabupaten Banyumas, Jawa Tengah e-mail: zulfatussobihah@gmail.com

\begin{tabular}{|c|c|c|}
\hline $\begin{array}{c}\text { Diterima: } \\
\text { 19 Desember 2019 }\end{array}$ & Revisi: & Disetujui: \\
\hline 25 Januari 2020 & 07 Maret 2020 \\
\hline D0I: & https://doi.org/DOI.10.32332/tarbawiyah.v4i1.1743 \\
\hline
\end{tabular}

Abstract

Keyword

Abstrak

Kata Kunci
This article describes the character education (akhlaq) which is a necessity in the midst of the nation's condition which is suffering from a multidimensional crisis, especially the moral crisis. The realization of someone with character (in the term of akhlaqul karimah religion) becomes everyone's dream, especially for parents. Character education is defined as moral education, moral values, moral education and character education which has the aim to develop one's ability to be able to give good and bad decisions, realize goto in all aspects of life. Therefore, character education will be carried out if it is aligned with the right education system and with qualified educators.

\section{Character Education, Akhlaqul Karimah, and Islamic education}

Artikel ini mendeskripsikan tentang pendidikan karakter (akhlak) yang merupakan suatu kebutuhan di tengah kondisi bangsa yang sedang terpuruk oleh krisis multidimensi, terutama krisis akhlak. Terwujudnya seseorang yang berkarakter (dalam istilah agama Akhlaqul Karimah) menjadi dambaan semua orang, terlebih bagi orang tua. Pendidikan karakter diartikan sebagai pendidikan akhlak, nilai budi pekerti, pendidikan moral serta pendidikan watak yang mempunyai tujuan untuk mengembangkan kemampuan seseorang untuk bisa memberikan keputusan baik buruk, mewujudkan kebagian dalam semua aspek kehidupan. Oleh sebab itu, pendidikan karakter akan terlaksana jika selaras dengan system pendidikan yang tepat serta dengan pendidik yang mumpuni.

Pendidikan Karakter, Akhlaqul Karimah, dan Pendidikan Islam 


\section{A. Pendahuluan}

Melihat perkembangan dunia pendidikan pada zaman sekarang ini, lebih khususnya dalam segi nilai moral yang dimiliki oleh generasi muda saat ini seperti sudah jarang sekali menemukan tujuan pendidikan yang sebenarnya yaitu "memanusiakan manusia". Dengan adanya tujuan yang seperti itu menandakan bahwa pendidikan sangatlah mulia. Namun sangat disayangkan, pada prakteknya para praktisi pendidikan pada lapangan masih jauh dari harapan. Oleh karenanya, hal inilah yang perlu diadakan evaluasi secara menyeluruh atas segala aspek yang berkaitan dengan pelaksanaan pendidikan di kalangan sekolah maupun lingkungan rumah dan sekitar.

Oleh karena itu, apakah ada yang salah dengan penerapan pendidikan di sekolah? Apakah pendidiknya tidak professional? Atau managemen sekolah yang kurang tepat? Atau bahkan memang peserta didiknya yang memang sulit untuk dikendalikan? Dengan demikian memang perlu adanya analisa lebih lanjut terhadap pelaksanaan pendidikan disemua lingkungan. Nantinya dengan adanya hasil analisa tersebut bisa kita ketahui hasil yang sebenarnya. Memang benar adanya ketimpangan atau tidak.

Namun sebenarnya tak hanya itu, untuk memberikan pendidikan karfakter tak hanya diberikan lewat pengetahuan umum saja. Perlu juga diberikan nila-nilai agama untuk mendukung pengembangan karakter seseorang. Karena biasanya karakter seseorang sangat berpengaruh dengan tingkat kepahamannya terhadap agama. Semakin dalam meraka memahami agama maka biasanya karakter seseorang semakin baik dan santun. Begitu sebaliknya, ketika seseorang belum bisa memahami nilai-nilai agama secara dalam makan karakter seseorang tersebut masih belum baik.

Selain itu, pembentukan karakter harus dilakukan secara sistematis dan berkesinambungan yang melibatkan aspek knowledge, feeling, loving dan action. Pembentukan karakter dapat diibaratkan dengan pembentukan sesorang menjadi body builder (binaragawan) yang memerlukan "latihan otot-otot akhlak" secara terus menerus agar menjadi kokoh dan kuat. Sebab pada dasarnya seseorang yang berkarakter rendah adalah seseorang yang tingkat perkembangan emosi-sosialnya rendah sehingga seseorang beresiko atau berpotensi 
besar mengalami kesulitan dalam belajar, berinteraksi sosial dan tidak mampu mengontrol diri. 1

Dengan adanya beberapa pemaparan diatas, bisa disimpulkan bahwa pendidikan karakter dalam Islam itu sangatlah penting. Maka harus lebih giat lagi untuk memberikan pemahaman Islam lebih mendalam lagi. Maka penulisa akan menyajikan beberapa penjelasan tentang pendidikan karakter dalam perspektif Islam.

\section{B. Memaknai Pendidikan, Pendidikan Karakter dan Tujuannya}

Berkaitan dengan term pendidikan, Orang-orang Yunani lebih kurang 600 tahun sebelum Masehi telah menyatakan bahwa pendidikan ialah usaha membantu manusia menjadi manusia. Ada dua kata yang penting dalam kalimat itu, pertama membantu dan kedua manusia. Manusia perlu dibantu agar ia berhasil menjadi manusia. Sejak dahulu banyak manusia gagal menjadi manusia. Maka dari itu, tujuan mendidik adalah memanusiakan manusia. Ada tiga syarat untuk dapat disebut sebagai manusia, yaitu; Pertama memiliki kemampuan dalam mengendalikan diri; Kedua cinta tanah air; dan Ketiga berpengetahuan. $^{2}$

Kemampuan mengendalikan diri atau yang disebut dengan emotional intelligence yang sering disingkat dengan EQ (Emotional Question) yang lebih dikenal dengan kecerdasan emosi. Salah satu contohnya adalah kemampuan mengendalikan diri, yakni sabar. Banyak orang menyesali perceraiannya tatkala ia mengucapkan talak dalam keadaan tidak mampu mengendalikan diri. Jika orang telah mampu mengendalikan diri itu berarti telah memiliki akhlak mulia dan dengan sendirinya akan mempunyai rasa cinta terhadap tanah air atau cinta pada tempat tinggal. Konsep inilah yang menjadi cikal bakal pelajaran kewarganegaraan. ${ }^{3}$

Manusia menjadi tujuan pendidikan harus mempunyai pengetahuan yang tinggi, dia juga harus mampu berfikir dengan benar. Orang Yunani beranggapan berpikir secara filsafat atau berfilsafat adalah

1 Asmaun Sahlan, Pendidikan Karakter dalam Perspektif Islam, (Malang, elHikmah UIN Malang), h. 140

${ }^{2}$ Ahmad Tafsir, Filsafat Pendidikan Islam, (Bandung, Remaja Rosdakarya, 2008), h. 33

${ }^{3}$ Ahmad Tafsir, Filsafat Pendidikan Islam 
latihan terbaik untuk mampu berpikir benar. Yang di atas adalah aspek pertama dari pendidikan yaitu tentang konsep manusia.

Adapun aspek pendidikan yang kedua dalah menolong. Setiap manusia pada dasarnya mempunyai potensi untuk menjadi manusia tetapi ada juga potensi untuk menjadi bukan manusia, misalnya menjadi binatang. Kegagalan pendidik dalam membantu manusia menjadi manusia itu memang ada tetapi hanya sedikit. Kata menolong juga menegaskan bahwa perbuatan mendidik itu hanya sekedar menolong. Kata "menolong" juga mengkiaskan agar pendidik tidak sombong, bila berhasil maka hasil itu adalah berkat usaha murid itu sendiri dan usaha dari orang lain atau pengaruh dari lainnya, sebagiannya merupakan hasil si pendidik. Kata "menolong' juga mengandung pengertian selalu kearah yang benar, jadi pendidik itu harus menolong murid dan pertolongannya itu harus berisi sesuatu yang benar. Karenanya pendidik tidak mengenal istilah mendidik anak mencuri atau mendidik anak membohong. Pendidikan dimulai menurut agama islam adalah sejak buayan sampai liang kubur. Para ahli pendidikan mengatakan bahwa pendidikan berlaku sepanjang hayat. Pendidikan berlangsung seumur hidup dengan mengesampingkan apakah dimulai sejak dalam rahim atau setelah lahir. Hakikat pendidikan dari segi lainnya adalah bahwa pendidikan ialah segala yang mempengaruhi seseorang. Maka dari itu pendidikan harus berlangsung seumur hidup karena manusia selama masih hidup selalu mendapat pengaruh dari berbagai pihak. Jadi selama manusia masih menghadapi masalah yang harus diselesaikan maka selama itu pula ia memerlukan pendidikan. ${ }^{4}$

Selanjutnya, berkaitan dengan pendidikan karakter. Pendidikan karakter merupakan gabungan dari dua bentuk kata yang berbeda. Pendidikan merupakan kata kerja, sementara karakter merupakan kata sifat. Istilah pendididkan merupakan terjemahan dari education, yang kata dasarnya educate atau bahasa latinnya educo, berarti mengembangkan dari dalam, mendidik, melaksanakan hukum kegunaan. Pendidikan juga bermakna sebuah proses yang membantu menumbuhkan, mengembangkan, mendewasakan, membuat yang tidak tertata atau liar menjadi semakin tertata, semacam proses

${ }^{4}$ Ahmad Tafsir, Filsafat Pendidikan Islam 
penciptaan sebuah kultur dan tata keteraturan dalam diri sendiri maupun diri orang lain. ${ }^{5}$

Dari segi etimologi, karakter berasal dari bahasa Yunani yang berarti "to mark" atau menandai atau memfokuskan bagaimana mengaplikasikan nilai kebaikan dalam bentuk tindakan atau tingkah laku, sehingga orang yang tidak jujur, kejam, rakus dan perilaku jelek lainnya dikatakan orang berkarakter jelek sebaliknya, oraang yang berperilaku sesuai dengan kaidah moral disebut dengan berkarakter mulia. Secara umum, istilah karakter sering diasosiasikan dengan apa yang disebut dengan temperamen yang memberinya, seolah definisi yang menekankan unsur psikososial yang dikaitkan dengan pendidikan dan konteks lingkungan. ${ }^{6}$ Sementara itu, dalam bahasa arab karakter disebut dengan istilah akhlak yang oleh Ibnu Maskawaih diartikan sebagai; hal linafs da'iyah laha ila af'aliha min ghair fikrin wa laa ruwiyatin (Sifat atau keadaan yang tertanam dalam jiwa yang paling dalam yang selanjutnya lahir dengan muda tanpa memerlukan pemikiran dan pertimbangan lagi). ${ }^{7}$

Dalam konteks pendidikan karakter, maka dapat dipaparkan bahwa istilah karaakter secara harfiah berasal dari bahasa latin "character", yang antara lain berarti watak, tabiat, sifat-sifat kejiwaan, budi pekerti, kepribadian atau akhlak. Sedangkan secara istilah, karakter diartikan sebagai sifat manusia pada umumnya dimana manusia mempunyai banyak sifat yang tergantung dari faktor kehidupannya sendiri. Karakter adalah sifat kejiwaan, akhlak atau budi pekerti yang menjadi ciri khas seseorang atau kelompok orang. Definisi dari " The stamp of individually or group impressed by nature, education or habit". Karakter merupakan nilai-nilai perilaku manusia yang berhubungan dengan Tuhan yang Maha Esa, diri sendiri, sesama manusia, lingkungan dan kebangsaan yang terwujud dalam pikiran, sikap, perasaan, perkataan dan perbuatan berdasarkan norma-norma agama, hukum, tata karma, budaya dan adat istiadat. Karakter juga dapat diartikan sama dengan akhlak dan budi pekerti, sehingga karakter bangsa identik dengan akhlak bangsa atau budi pekerti bangsa. Bangsa yang berkarakter adalah bangsa yang berakhlak dan

${ }^{5}$ Arif Billah, Pendidikan Karakter Untuk Anak Usia Dini Dalam Perspektif Islam dan Implementasinya Dalam Materi Sains, (Salatiga: IAIN Slatiga, 2016), h. 251

6 Doni Koesoema A, Pendidikan Karakter, (Jakarta; Grasindo, 2010), h. 79

7 Doni Koesoema A, Pendidikan Karakter 
berbudi pekerti, sebaliknya bangsa yang tidak berkarakter adalah bangsa yang tidak atau kurang berakhlak atau tidak memiliki standar norma dan perilaku yang baik. ${ }^{8}$

Pendidikan karakter adalah pendidikan yang membentuk kepribadian seseorang melalui pendidikan budi pekerti, yang hasilnya terlihat dalam tindakan seseorang yaitu tingkah laku yang baik dan jujur, bertanggung jawab, menhormati hak orang lain, kerja keras dan sebagainya. ${ }^{9}$ Dalam buku 100 Ways to Enhance Value and Morallity in School and Youth Setting, Howard Krischenbaum menguraikan 100 cara untuk bisa meningkatkan nilai dan moralitas (karakter/akhlak mulia) di sekolah yang bisa dikelompokkan kedalam lima metode, yaitu: inculcating value and morality (penanaman nilai dan moralitas), modeling value and morality (pemodalan nilai-nilai dan moralitas), facilitating value and morality (menfasilitasi nila-nilai dan moralitas), skills for value development and moral literacy (ketrampilan untuk pengembangan nilai dan literasi moral), dan developing a value aducation program (mengembangkan program pendidikan nilai). ${ }^{10}$

Berdasarkan pada pengertian diatas, dapat dipahami bahwa pendidikan merupakan sebuah proses membimbing dan mengembangkan potensi dalam diri seseorang agar terarah ke jalan yang baik dengan cara yang baik pula sehinggat terbentuk pribadi yang baik dan santun. Dan dalam proses pengembangannya, dilakukan secara sadar dan tulus agar tujuan yang diinginkan dapat tercapaik dengan baik.

Sebagaimana disebutkan Ajat Sudrajat, bahwa pendidikan karakter memiliki beberpa tujuan, yaitu;

1. Mengembangkan potensi kalbu/nurani/afektif peserta didik sebagai manusia dan warga Negara yang memiliki sikap dan perilaku yang mencerminkan budaya dan karakter bagus.

2. Mengembangkan kebiasaan dan perilaku peserta didik yang terpuji dan sejalan dengan nilai-nilai universal dan tradisi budaya bangsa yang religious.

3. Menanamkan jiwa kepemimpinan dan tanggung jawab peserta didik sebagai generasi penerus bangsa.

\footnotetext{
${ }^{8}$ Asmaun Sahlan, Pendidikan Karakter dalam Perspektif Islam, h. 141

${ }^{9}$ Hilda Ainissyifa, Pendidikan Karakter dalam Perspektif Pendidikan Karakter, (Garut, Universitas Garut, 2014), h. 5

10 Marzuki, Konsep Dasar Pendidikan Karakter, (Yogyakarta: UNY, 2008), h. 9
} 
4. Mengembangkan kemampuan peserta didik menjadi manusia yang mandiri, kreatif, berwawasan kebangsaan.

5. Mengembangkan lingkungan kehidupan sekolah sebagai lingkungan belajar yang aman, jujur, penuh kreatifitas, dan persahabatan, serta dengan rasa kebangsaan yang tinggi dan penuh kekuatan. ${ }^{11}$

Tujuan pendidikan karakter merupakan arah dalam pelaksanaan pendidikan dalam sebuah lembaga. Pada era sekarang ini, pendidikan karakter sangatlah penting untuk membantu dalam menghadapi krisis moral yang melanda bangsa Indonesia. Dengan demikian, maka trend pendidikan mengalami pergeseran orientasi yang menempatkan pembangunan manusia seutuhnya melalui pendidikan dan latihan dengan beragam jenis, jenjang, sifat dan bentuknya. Pendidikan manusia seutuhnya diidealisasikan menjadi titik puncak tercapainya pendidikan yang saat ini menjadi dambaan. Sosok yang diidolakan belum juga dihasilkan, maka lembaga pendidikan dijadikan ekspetasi alternatif sebagai instrumen pertama proses kemanusiaan dan pemanusiaan, yaitu menghargai dan memberi kebebasan untuk berpendapat dan berekspresi. Pendidikan sebagai pembentuk karakter semacam ini tidak bisa dilakukan dengan cara mengenali dan menghafal jenis-jenis karakter manusia yang dianggap baik saja, melainkan harus lewat pembiasaan dan praktik nyata dalam kehidupan seharihari. 12

Seorang guru bertugas merawat dan menjaga agar karakter kebaikan tersebut muncul serta mendoringnya agar menjadi aktual dalam kehidupan sehari-hari, prinsip-prinsip dalam pendidikan yang tujuan utamanya adalh membentuk karakter peserta didik, antara lain: Pertama, manusia merupakan makhluk yang dipengaruhi oleh dua aspek, yaitu: kebenaran yang ada dalam dirinya dan dorongan (kondisi) eksternal yang mempengaruhi kesadarannya. Kedua, konsep pendidikan dalam rangka membangun karakter peserta didik sangat menekankan pentingnya kesatuan antara keyakinan, perkataan dan perbuatan. Ketiga, pendidikan karakter menutamakan munculnya kesadaran pribadi peserta didik untuk secara ikhlas mengutamakan karakter positif dalam dirinya. Keempat, pendidikan karakter

${ }^{11}$ Ajat Sudrajat, Mengapa Pendidikan Karakter?, (Yogyakarta, UNY, 2016), h. 21

12 Asmaun Sahlan, Pendidikan Karakter dalam Perspektif Islam, h.141 
mengarahkan peserta didik untuk menjadi manusia yang ulul albab yang tidak hanya memiliki kesadaran untuk terus mengembangkan dirinya, memperhatikan masalah, lingkungannya dan memperbaiki kehidupan sesuai dengan pengetahuan dan karakter yang dimilikinya. Kelima, karakter seseorang ditentukan oleh apa yang dilakukan berdasarkan pilihan bebasnya.

Dengan adanya paparan tersebut, maka jelas pendidikan karakter sangat penting dalam kehidupan manusia khususnya kaderkader muda yang sebagai penerus bangsa yang sekarang ini ditempuh dengan dekadensi moral di berbagai lembaga, termasuk dalam dunia pendidikan. Karena salah satu yang bisa memperbaiki bangsa ini adalah dengan memperbaiki karakter mereka, utamanya di lingkungan keluarga dan lingkungan sekolah, khususnya di lembaga pendidikan Islam.

\section{Pendidikan Karakter dalam Perspektif Islam dan Prinsip- prinsipya}

Dalam konteks ini, Pendidikan Islam seharusnya menjadi pendidikan yang bergerak "dari dalam ke luar" yakni pendidikan yang bertumpu pada pembentukan karakter pada setiap individu yang akan secara dinamis bergerak membentuk karakter kelompok, jamaah, dan umat. Pendidikan ini dalam islam disebut dengan pendidikan akhlak. Allah selalu menargetkan kondisi makarim al-akhlaq dalam pencapaian target pendidikan. Ada banyak ayat al-Qur'an yang membahas tentang konsep pencapaian akhlak terpuji, diantaranya dalam QS. Al-Baqarah ayat 282; QS. An-Nisa ayat 9; QS. Al-A'raf ayat 31; QS. Yunus ayat 101; QS. Al-Ahqaf ayat 15; QS. An-Nahl ayat 90; QS. Al-Isra ayat 26; QS. AnNur ayat 27; dan QS. Al-Muthofifin ayat 1-3.13

Akhlak atau karakter sangat penting, karena akhlak merupakan kepribadian yang mempunyai tiga komponen, yaitu tahu (pengetahuan), sikap, dan perilaku. Hal tersebut menjadi penanda bahwa seseorang layak atau tidak layak disebut manusia. Karakter adalah watak, sifat, atau hal-hal yang memang sangat mendasar yang ada pada diri seseorang. Hal-hal yang sangat abstrak yang ada pada diri seseorang. Sering orang menyebutnya dengan tabiat atau perangai.

13 Siti Farida, Pendidikan Karakter Dalam Perspektif Islam, (Sampang: STAI Nazhatut Thullab, 2016), h. 205 
Dalam pandangan Islam bahwa pendidikan karakter dalam Islam yang memiliki keunikan dan perbedaan dengan pendidikan karakter di dunia Barat. Perbedaan- perbedaan tersebut mencakup penekanan terhadap prinsip-prinsip agama yang abadi, aturan dan hukum dalam memperkuat moralitas, perbedaan pemahaman tentang kebenaran, penolakan terhadap otonomi moral sebagai tujuan pendidikan moral, dan penekanan pahala di akhirat sebagai motivasi perilaku bermoral, yang sebagaimana diungkapkan oleh Allah dalam firman-Nya pada QS. al-Baqarah yang artinya: "Jika kamu melahirkan sesuatu kebaikan atau menyembunyikan atau memaafkan sesuatu kesalahan (orang lain), maka sesungguhnya Allah maha pema'aflagi maha kuasa". Berdasarkan pada ayat tersebut, maka akhlak dalam Islam sangat mulya dan agung bagi orang mampu melakukannya.

Dengan berbagai penjelasan di atas, yang berkaitan dengan pendidikan karakter dalam perspektif Islam, maka dapat dijelaskan bahwa pendidikan karakter dalam Islam sama halnya dengan "akhlak". Sehingga pendidikan karakter dalam pespektif Islam lebih menitikberatkan pada sikap peserta didik, yang hal tersebut pada kehendak positif yang dibiasakan, sehingga dia mampu menimbulkan perbuatan dengan mudah, tanpa pertimbangan pemikiran lebih dahulu dalam kehidupan sehari-hari.

Adapun kedudukan akhlak dalam Islam amatlah penting, sebagaimana disebutkan dalam Hadits Rasulullah SAW, yang artinya "Sesungguhnya aku diutus untuk menyempurnakan akhlak manusia". Bahkan, dikatakan bahwa definisi agama adalah berakhlak mulia, sebagaimana Hadits Rasulullah saw: "Rasulullah ditanya: "Apakah agama itu? Beliau menjawab: "Agama adalah akhla mulia". Berakhlak mulia adalah bukti kesempurnaan iman, sebagaimana Hadits Rasulullah saw: "Sesungguhnya orang mukmin yang paling mulia adalah yang paling baik akhlaknya, dan sebaik-baiknya kalian adalah yang paling baik terhadap istri- istrinya". Berakhlak mulia menjadi penyebab masuk surga dan selamat dari api neraka, sebagaimana hadits Rasulullah saw: "Sesungguhnya Rasulullah saw. Ditanya tentang (penyebab) banyaknya orang masuk surga, beliau menjawab: "Bertaqwalah kepada Allah swt dan berkhlak mulia". Dan beliau ditanya tentang (penyebab) banyaknya orang masuk nereka, beliau menjawab: "mulut dan kemaluan (akhlak tercela)". Dalam kontek ini, Islam menganjurkan agar kita berakhlak mulia dengan mencontoh perilaku Nabi Muhammad SAW., karena 
dalam diri beliau terdapat suri tauladan yang baik. ${ }^{14}$ Selanjutnya, dalam perihal konflik, Islam menempuh tindakan preventif dengan cara menghadapi perbuatan buruk dengan perbuatan baik, dengan demikian permusuhan dapat berubah menjadi persahabatan. ${ }^{15}$ Islam juga mengajak umat manusia untuk bersegera memohon ampun kepada Allah swt dengan seraya menafkahkan hartanya, menahan amarah dan memaafkan kesalahan orang lain. ${ }^{16}$

Dengan demikian jelas bahwa pendidikan karakter dalam perspektif Islam memang diidentik dengan kata-kata "akhlak", sehingga pendidikan tersebut selalu bermuara pada akhlak. Selain itu pula, akhlak merupakan corak seseorang atau penentu bahwa orang tersebut baik ataupun buruk, sehingga dengan inilah akhlak selalu dijadikan penentu paling terdepan dalam setiap persoalan. Termasuk dalam membangun bangsa Indonesia, khususnya dalam pembinaan anak-anak muda.

Selanjutnya, didalam pendidikan karakter terdapat dua prinsipyang harus ditempuh, yaitu;

1) Prinsip Pertama

Percaya bahwa akhlak itu termasuk diantara makna yang terpenting dalam hidup ini. Tetapi perlu diingat bahwa akhlak tidak terbatas pada penyusunan hubungan antara manusia dengan manusia lain, tetapi melebihi itu, juga mengatur hubungan antara hamba dengan Tuhannya. Akhlak menurut pengertian islam adalah salah satu hasil dari iman dan ibadah; bahwa iman dan ibadah manusia tidak sempurna kecuali kalau timbul dari situ akhlak mulia dan mu'amalah yang baik terhadap Allah dan mahluknya dan bahwa akhlak yang mulia yang diminta dari muslim untuk berpegang teguh padanya harus dipelihara bukan hanya terhadap makhluk saja, tetapi juga wajib dan lebih-lebih lagi terhadap Allah dari segi akidah dan ibadah. ${ }^{17}$

Di antara tanda-tanda iman yang paling menonjol pada akhlak yang mulia dan diantara tanda-tanda nifak yang paling menonjol adalah akhlak yang buruk. Diantara perhiasan yang paling mulia bagi manusia sesudah iman, taat dan takut kepada Allah adalah akhlak yang mulia.

\footnotetext{
${ }^{14}$ Lihat dalam QS. al-Qalam ayat 4., dan QS. al-Ahzab ayat 21.

15 Lihat juga dalam QS. Fushilat ayat 34, QS. Al- Mu'minun ayat 96

${ }^{16}$ Hal ini termaktub dalam QS. Ali Imran ayat133-134. Lebih lengkap lihat dalam Asmaun Sahlan, Pendidikan Karakter dalam Perspektif Islam, h. 146

17 Omar Mohammad, Falsafah Pendidikan Islam, (Jakarta, Bulan Bintang, 1979), h. 312
} 
Dengan akhlak ini terciptalah kemanusiaan manusia itu dan perbedaanya dengan hewan. Ada diantara keutamaan akhlak yang termasuk ibadah kepada Allah seperti keutamaan takwa, taat dan takut kepada Allah.

Terdapat di dalam al-Qur'an sebanyak 1504 ayat yang berhubungan dengan akhlak, baik dari segi teori atau segi praktis. Jadi kadar ini merupakan hampir seperempat ayat al-qur'an. Di antara ayatayat ini adalah firman Allah sewaktu memuji Nabi Muhammad saw. pada QS. al-Qalam ayat 4 yang artinya: "Sesungguhnya engkau berada pada akhlak yang mulia." Ayat ini menyatakan akhalak sebagai sifat nabi yang paling mulia, dan pujian tertinggi yang dapat diberikan kepadanya. Sebab akhlak Nabi saw tiada lain dari pada pelaksanaan praktis bagi makna kesempurnaan, kesopanan dan akhlak yang baik yang terdapat pada al-Qur'an.

Jadi yang baru dalam Islam atau dalam al-Qur'an dan Sunnah Nabi "adalah menyempurnakan", tidak membuat segala keutaman yang baru, sebab banyak keutamaan-keutamaan telah dikenal dan diterima sebelum Islam, tetapi bercerai berai, bertentangan satu sama lain dan bersifat kurang. Dengan demikian akhlak yang mulia adalah dasar pokok untuk menjaga semua kalangan, dan oleh sebab akhlak itulah timbulnya amal shaleh yang berguna untuk kebaikan umat dan masyarakat.

\section{2) Prinsip Kedua}

Percaya bahwa akhlak itu adalah kebiasaan atau sikap yang mendalam dalam jiwa dari mana timbul perbuatan-perbuatan dengan mudah dan gampang. Ia juga "suatu faktor yang mempengaruhi perilaku manusia dan pada kebolehannya untuk menyesuaikan kebolehannya untuk menyesuaikan kebolehannya untuk menyesuaikan dirinya dengan alam sekitar" tempat hidup. Konsep akhlak seperti Ibnu Maskawaih dan Al-Ghazali mengatakan bahwa akhlak itu "suatu keadaan atau bentuk jiwa dari mana timbul perbuatanperbuatan tanpa pikir dan usaha." Akhlak dalam pemikiran islam bahwa akhlak membuat pandangan Islam bukan sekedar kata-kata yang diulang-ulang dan slogan yang dipamerkan, tetapi ia adalah watak atau kebiasaan atau sikap yang mendalam, dijiwai, bekerja sama dalam 
membentuknya berbagai faktor warisan yang meerupakan kecerdasan, naluri, dan lainnya. 18

Diantara bukti yang diberikan oleh filosof-filosof akhlak orangorang Islam untuk menunjukan mungkinnya mengubah akhlak adalah firman Allah dalam QS. Ar-Ra'du ayat 11 yang artinya; "Allah tidak akan mengubah apa yang ada pada suatu kaum sehingga mereka mengubah diri mereka sendiri." Hal ini menunjukkan makna bahwa manusia tidak dapat mengubah keadaan jiwanya dan keadaan akhlaknya. Hal tersebut juga sejalan dengan sabda Rasulullah saw bahwa kita diperintahkan untuk memperbaiki akhlak.

\section{Kesimpulan}

Dengan adanya beberapa pemaparan dan penjelasan di atas, maka dapat kita simpulkan bahwa pendidikan dalam perspektif Islam adalah karakter yang sama halnya dengan akhlak. Hal itulah yang mendasari pendidikan karakter lebih menekankan pada sikap seseorang atau peserta didik yang mencoba untuk membiasakan kebiasaan baik agar dengan mudah dalam melakukan hal kebaikan tanpa perlu adanya pertimbangan. Kedudukan akhlak sangatlah penting dalam setiap aspek kehidupan. Oleh karenanya Allah mengutus Nabi Muhammad untuk memperbaiki akhlak manusia. Akhlak merupakan identitas seseorang atau corak seseorang sebagai penentu bagaimana seseorang memahami Islam dengan dalam. Akhlak seseorang dapat dilihat dari seberapa paham seseorang dalam memahami islam itu sendiri. Ketika pemahaman terhadap agama rendah maka akhlak seseorang tersebut akan buruk.[]

\section{Daftar Pustaka}

Ainissyifa. Hilda, Pendidikan Karakter dalam Perspektif Pendidikan Karakter, Garut: Universitas Garut, 2014.

Billah, Arif. Pendidikan Karakter Untuk Anak Usia Dini Dalam Perspektif Islam dan Implementasinya Dalam Materi Sains, Salatiga; IAIN Salatiga, 2016.

18 Omar Mohammad, Falsafah Pendidikan Islam, h. 319 
Farida, Siti. Pendidikan Karakter Dalam Perspektif Islam, Sampang: STAI Nazhatut Thullab, 2016.

Koesoema, Doni A. Pendidikan Karakter, Jakarta; Grasindo, 2010

Marzuki, Konsep Dasar Pendidikan Karakter, Yogyakarta: UNY, 2008

Mohammad, Omar. Falsafah Pendidikan Islam, Jakarta: Bulan Bintang, 1979

Nurma, Ali Ridwan. Konsepsi Pendidikan Karakter Dalam Perspektif Islam, Yogyakarta: Universitas Muhamadiyyah Yogyakarta, 2013.

Sahlan, Asmaun. Pendidikan Karakter dalam Perspektif Islam, Malang, el-Hikmah UIN Malang

Sudrajat, Ajat. Mengapa Pendidikan Karakter?, Yogyakarta: UNY, 2016

Tafsir, Ahmad. Filsafat Pendidikan Islam, Bandung, Remaja Rosdakarya, 2008. 